\title{
Comparison of Basal Serum Testosterone Levels between Male Athletes and Martial Artists
}

\author{
Comparación de niveles basales de testosterona sérica entre hombres deportistas y artistas \\ marciales
}

\author{
Roberto Arjona-Luna \\ Corresponding Author: Roberto Arjona Luna, Departamento de Rehabilitación Física y Kinesiología Deportiva. Ignition Salud Integral. \\ San Luis Potosí, San Luis Potosí. México, E-mail: dr.arjona@hotmail.com,Tel.01524441001229.
}

\begin{abstract}
:
There are reports about the relationship between testosterone levels and aggressiveness in animals and humans. The practice of martial arts requires high levels of pain tolerance, fear control and of course, enough aggressiveness to overcome psychological and biological stress. Therefore, the objective of the present study was to identify the relationship between basal testosterone levels and martial arts practice by comparing total serum testosterone values between male athletes and martial artists. In this cross-sectional study, the total testosterone between a control group of 15 male athletes and 15 male martial artists was compared. The participants had the following inclusion criteria: healthy men between 18 and 35 years old, not obese, with at least 1 year of continuous training, 3 to 5 sessions per week with a duration from 60 to $90 \mathrm{~min}$ at a moderate to high intensity, non smokers, alcohol free, and free from exogenous testosterone or testosterone precursors. Blood samples were recolected between 8:00 to 10:00 am and the laboratory results were obtained by chemiluminescence. The testosterone levels mean of the martial artist's group was $6.44( \pm 1.17) \mathrm{ng} / \mathrm{mL}$ and the athlete's control group had a mean of $6.09( \pm 1.32) \mathrm{ng} / \mathrm{mL}$. Comparing values with the Student's t-test showed no statistically significant difference, with a $\mathrm{p}$ value of 0.45 . There is no significant difference of basal total testosterone levels between male martial artists and athletes, and it seems there is no direct relationship between testosterone levels and martial arts practice. Further investigation on the physiologic responses produced by the practice of combat sports is a growing necessity.
\end{abstract}

Key words:

Testosterone, Martial Arts, Sports, Physiology, Sports Medicine

\begin{abstract}
Resumen:
Existen reportes sobre la relación entre los niveles de testosterona y la agresividad tanto en humanos como en animales. La práctica de artes marciales requiere de tolerancia al dolor, control del miedo y por supuesto, suficiente agresividad para superar el estrés psicológico y biológico. Por lo tanto, el objetivo del presente estudio fue el de identificar la relación entre los niveles basales de testosterona y la práctica de artes marciales, al comparar los valores de testosterona total sérica entre hombres deportistas y artistas marciales. En este estudio de corte transversal, se realizó la comparación de la testosterona total entre un grupo control de 15 hombres deportistas y 15 hombres artistas marciales. Los participantes cumplieron los siguientes criterios de inclusión: hombres sanos de 18 a 35 años, sin obesidad, con 1 año mínimo de práctica deportiva o de artes marciales, entrenamiento de 3 a 5 veces a la semana y un promedio de 60 a 90 min por sesión a una intensidad media-alta, no fumadores ni alcohólicos, y libres de testosterona exógena o precursores de testosterona. Las muestras sanguíneas se obtuvieron de las 8:00 a las 10:00 am y los resultados de laboratorio se obtuvieron por quimioluminiscencia. La media del nivel de testosterona del grupo de artistas marciales fue de $6.44( \pm 1.17) \mathrm{ng} / \mathrm{mL} \mathrm{y}$ la media del grupo control de deportistas fue de $6.09( \pm 1.32) \mathrm{ng} / \mathrm{mL}$. Al comparar las medias con el examen de T-Student, no se encontró diferencia estadística significativa con un valor $\mathrm{p}=0.45$. No existen diferencias significativas entre los niveles basales de testosterona total sérica de hombres artistas marciales y deportistas, y al parecer no existe relación directa entre la práctica de artes marciales y los valores de testosterona. Futuras investigaciones sobre las respuestas fisiológicas producto de la práctica de artes marciales son una necesidad creciente.
\end{abstract}

\section{Palabras Clave:}

Testosterona, Artes Marciales, Deporte, Fisiología, Medicina del Deporte 


\section{Introduction}

Since ancestral times, diverse cultures have practiced martial arts as a defense and attack method. Currently we may see its evolution and competitive practice in combat sports. Nowadays people practice them seeking an increase in aerobic resistance and muscle power, fat loss, personal defense or to help correcting conduct problems. ${ }^{1-4}$ Combat sports may be catalogued in striking sports (Box, Karate, Tae Kwon Do, Kickboxing, Muay Thai), wrestling (Judo, Brazilian Jiu-Jitsu, Sumo, Greco Roman Wrestling) and hybrids (MMA, Krav Maga, Sambo). ${ }^{5,6}$ Martial arts and combat sports recreate a situation in which an individual should defeat another physically and mentally. Valid attacks are: striking, kicking, throw downs, joint locks and chokeholds. Fights are won by points (strikes or dominant positions over the opponent), submissions (rival abandons combat voluntarily) or judge decision (KO, injury or unconsciousness). ${ }^{7}$ Hand-to-hand combat requires high levels of pain tolerance, fear control and of course, enough aggressiveness to overcome psychological and biological stress. What inclines an athlete to combat sports? Is there a physiological tractor that influences someone to practice martial arts? A determinant factor could be aggressiveness and testosterone levels. ${ }^{5-10}$

There is a proportional relationship between aggressiveness and testosterone levels in different species, and obviously, humans are no exception. ${ }^{8}$ Testosterone is an androgenic sexual hormone that has different organic effects: increase in muscle mass and bone density, lipid regulation, secondary sex characteristics development, sex drive increase, and diverse cognitive and emotive functions of the brain., ${ }^{9,10}$ Aggressiveness is generated by emotional impulses from the amygdala and hypothalamus. Afterwards, that information is processed, selected and suppressed by the prefrontal cortex. Testosterone activates the amygdala creating emotions that may be resistant to prefrontal cortex control. On the other hand, serotonin and cortisol stimulates cortical control of aggressive emotions, antagonizing the testosterone effect. ${ }^{11}$ It is imperative to study aggression in sports, primarily in those cases where physical contact or combat is involved, as aggressive conducts are frequently experienced and reproduced. ${ }^{12,13}$ Anger is energy done that an athlete uses with the objective of winning a tactical advantage over his adversary. ${ }^{14}$ This way, a competitor should use anger emotion to lead more energy towards his executions with the purpose of achieving his sports goal. It has been proven that martial artists believe that sport success is bound to a higher aggressiveness level. ${ }^{15,16}$ Studies conducted with monozygotic twins ${ }^{17}$ and randomized clinical trials ${ }^{18}$ have proven that supraphysiologic doses of testosterone increases aggressiveness and cognitive impairment. In some sports, like martial arts, higher testosterone levels would be desirable due to the importance of aggressiveness and physical contact. It has been reported a direct relationship between physiologic testosterone levels and the number of attacks made by Judo practitioners ${ }^{19}$, also a higher pre-competition testosterone value has been related to less fatigue and a vigorous mental state. ${ }^{20,21}$ High testosterone levels have been reported in several sports, but this has been related to exogenous administration of this hormone, seeking an increment in muscle mass, strength and endurance. ${ }^{22,23}$ It is important to mention that supraphysiologic values are banned by athletic committees and represent a health $\operatorname{hazard}^{24,25}$
Previous comparative studies of basal serum testosterone levels between sedentary men and athletes show no significant differences. ${ }^{26-28}$ Nevertheless, no studies have compared martial artists and athletes up to date. Therefore, the objective of this research was to compare basal serum testosterone levels between male athletes and martial artists with the final purpose of identifying any relationship between physiologic testosterone levels and combat sports practice. A higher, but physiological normal level, in the martial artists group will be necessary to confirm this hypothesis. A secondary objective was to observe how a mixed modality and moderate-high intensity exercise affects basal serum testosterone levels in healthy men.

\section{Materials and Methods}

This cross-sectional study was performed in the Sports Rehabilitation and Kinesiology Department. Ignition Salud Integral. San Luis Potosí, San Luis Potosí. México. Two groups were selected, each one included 15 male participants. A control group of athletes (Rugby $n=7$, Soccer $n=2$ and Weight Lifting $\mathrm{n}=6$ ) and a martial artists group (Brazilian Jiu-jitsu $n=10$ and Mixed Martial Arts $n=5$ ). Both groups complied with the following characteristics: healthy men between 18 and 35 years old, not obese, with at least 1 year of continuous training, 3 to 5 training sessions per week with a duration from 60 to 90 minutes of moderate to high intensity, nonsmokers, alcohol free, and free from exogenous testosterone or testosterone precursors. Obesity was defined as a body mass index $\geq 30$ $\mathrm{kg} / \mathrm{m}^{2}, \mathrm{BMI}=$ weight in kilograms divided by the square of the height in meters. ${ }^{29}$ Total serum testosterone determination was elected as it is has the most sensitivity, specificity and reproducibility within the current testosterone measurement techniques. ${ }^{30,31}$ Participants avoided sexual intercourse, long trips, exercising, drinking alcohol or smoking 24 hours before blood-sample taking, to prevent hormone alterations. ${ }^{32}$ Blood samples were obtained between 8:00 am to 10:00 am according with the highest concentrations of this hormone in the blood. No special preparatory methods including fasting was needed. The normal reference range was taken from the American Society of Endocrinology which is from 3.00 to $8.66 \mathrm{ng} / \mathrm{mL}$. $^{33}$ 2.1 Total Serum Testosterone Measurement

The serum testosterone results were obtained by chemiluminescence and expressed in $\mathrm{ng} / \mathrm{ml}$.

2.2 Statistical Analysis

SPSS software was used for statistical analysis. Shapiro-Wilk test evaluated normal distribution of data. Student's t-test for two independent means was used with a significance level of $\mathrm{p}<0.05$.

\section{Results}

A total of 30 participants finalized the study. All basal serum testosterone data had a normal distribution according to Shapiro-Wilk Test. The athlete's group testosterone level mean was $6.09( \pm 1.32) \mathrm{ng} / \mathrm{mL}$ and the martial artists mean was 6.44 $( \pm 1.17) \mathrm{ng} / \mathrm{mL}$. The body mass index mean in the control group was of $24.6( \pm 0.7) \mathrm{kg} / \mathrm{m}^{2}$ and in the martial artist's group of 24.3 $( \pm 1.3) \mathrm{kg} / \mathrm{m}^{2}$. Table 1 shows the basal serum testosterone levels and the age of the participants of both groups. By comparing the basal serum testosterone values between both groups with the Student's t-test, it showed no significant statistical difference, rejecting the alternative hypothesis with a $\mathrm{p}$ value of 0.45 
(Figure 1). When analyzing all 30 participants as only one group $(n=30)$, the total serum testosterone mean was of $6.26( \pm 1.24)$ $\mathrm{ng} / \mathrm{mL}$ and the age mean of $25.3( \pm 4.7)$ years old.

\section{Discussion}

In this study, the martial artists group obtained higher testosterone levels $(6.44 \mathrm{ng} / \mathrm{mL}$ versus $6.09 \mathrm{ng} / \mathrm{mL})$ than the control group, nevertheless this difference was not statistically significant $(\mathrm{P}>0.05)$. Certainly, the sample size was the main methodological limitation, considering that ideally a bigger size group would have been better. However, the majority of studies related to the subject have used similar samples. Both groups had testosterone levels inside physiological parameters. The body mass index has been related to testosterone levels. In this sense, several studies have described that the serum total testosterone level is inversely proportional to obesity ${ }^{34-36}$, due to insulin resistance-associated reductions in sex hormone binding globulin ${ }^{37}$. To avoid this, all participants had a BMI below $30 \mathrm{~kg} / \mathrm{m}^{2}$.

An important factor to consider is the participants' age (from 18 to 35 years old) because testosterone values may decrease after that. $^{38-40}$ In the present study, both groups had a normal distribution and the age means were not significantly different $(\mathrm{p}>0.05)$.

Another fundamental variable is the effect of exercising on basal serum testosterone values. In general, it is accepted that a moderate intensity exercise either of resistance or strength training, increases serum testosterone levels in the post-training period. ${ }^{41-45}$ However, high intensity and long-lasting exercise may decrease testosterone plasmatic concentrations below resting values. Although, it seems to exist an intensity and duration threshold from which testosterone production declines. ${ }^{46-48}$ The participants had similar training characteristics: Mixed modality training (endurance and strength), 3 to 5 sessions per week, 60-90 min per session and moderate-high intensity.

Martial arts demand both physical capacities, with a $\mathrm{VO}_{2 \max }$ from 42 to $52 \mathrm{~mL} / \mathrm{kg} / \mathrm{min}$ and a high muscle power and strength component ${ }^{49}$, because in combat, many decisive actions are sudden and explosive..$^{50,51}$ Studies show a direct relationship between sport success and anaerobic capacity in combat sports. $^{52}$

When analyzing all 30 participants involved $(n=30)$ the total serum testosterone levels mean was of $6.26( \pm 1.24) \mathrm{ng} / \mathrm{mL}$. It is inferred that a mix modality and moderate-high intensity training does not decrease basal serum testosterone levels in healthy men.

The lack of significant differences of testosterone levels between the two groups indicates that the relation among martial arts or combat sports practice and aggressiveness is not bound to basal testosterone levels. In addition, testosterone secretion triggered by external aggressive stimuli seems dependent to social, cultural, and educational factors. ${ }^{53}$ It has been observed that a hostile environment that causes constant aggressive attitudes eventually leads to different patterns of aggressiveness and hormonal production in the presence of this stimulus. $^{54}$

The "Challenge" hypothesis proposes that due to the high metabolic cost, organisms should seek a balance between production and demand of testosterone regarding the needs imposed by the environment. ${ }^{55}$ It has been suggested that aggressiveness related to testosterone production is mainly because of a social status challenge ${ }^{56}$ and reproductive opportunities $^{57}$, not when it is a defense reaction. Further investigation is needed, but a hypothesis would be that constant practice of martial arts or combat sports modulate hormonal secretion and its physiological and behavioral responses. It is possible that due to training and constant exposure to physical aggression inside a controlled environment, the martial artist can generate physiological adaptations to handle better physical and mental stress, thus it is of great importance to obtain a strategic advantage and defeat an opponent. This will explain why martial arts have been recommended to deal with discipline, impulse control, and abuse problems. ${ }^{59}$

\section{Conclusions}

There are no significant differences between basal serum testosterone levels of martial artists and athletes, so there is no direct relationship between martial arts practice and testosterone values. Mix modality training (aerobic and anaerobic) with moderate-high intensity and volume does not decrease basal testosterone levels in healthy men. This conclusion is useful for physicians, trainers and patients for the following reasons: a. The practice of martial arts is not the cause of high testosterone levels in athletes; b. Recommending martial arts practice as adjunctive treatment of hypogonadism, it will not be better than practicing other sports; and c. Inclination towards combat sports is a cognitive decision, not a hormonal response. This supports the idea that aggressive behavior should be approached from a behavioral, not only biological perspective.

\section{References}

Rainey CE. Determining the prevalence and assessing the severity of injuries in mixed martial arts athletes. Therapy N Am J Sports Phys Ther. 2009; 4: 190-99.

Zetaruk MN, Violán MA, Zurakowski D, Micheli LJ. Injuries in martial arts: a comparison of five styles. Br J Sports Med. 2005; 39: 29-33.

Kreiswirth EM, Myer GD, Rauh MJ. Incidence of injury among male brazilian jiujitsu fighters at de world jiu-jitsu no-gi championship 2009. J Athl Train 2014; 49: 89-94.

Bledsoe GH, Hsu EB, Grabowski JG, Brill JD, Li G. Incidence of injury in profesional mixed martial arts competitions. J Sports Sci Med. 2006; CSSI, 136-42.

Lystad RP, Gregory K, Wilson J. The epidemiology of injuries in mixed martial arts: a systematic review and meta-analysis. Orthop J Sports Med. 2014; 2(1): 1-10.

Lystad RP. Epidemiology of injuries in full-contact combat sports. Australas epidemiol 2015; 22: 114.

Couto de Souza JM, Faim FT, Nakashima IY, Altruda CR, Medeiros WM Reis da Silva L. Lesions in Shotokan karate and jiujitsu- direct trauma versus indirect. Rev Vras Med Esporte. 2011; 17: 107-10.

Giammanco M, Tabacchi G, Giammanco S, Di Majo D, La Guardia M. Testosterone and agressiveness. Med Sci Monit. 2005; 11: 136-45.

Goodale T, Sadhu A, Petak S, Robbins R. Testosterone and the Heart. Methodist Debakey Cardiovasc J. 2017; 13: 68-72.

Wood RI, Stanton SJ. Testosterone and sport: current perspectives. Horm Behav. 2012; 61: 147-55.

Batrinos ML. Testosterone and Aggressive Behavior in Man. Int J Endocrin Metab. 2012; 10: 563-568.

Robazza C, Bortoli L, Nougier V. Performance-related emotions in skilled athletes: hedonic tone and functional impact. Percept Mot Skills. 1998; 87: 547-64.

Robazza C, Bertollo M, Bortoli L. Frequency and direction of competitive anger in contact sports. J Sports Med Phys Fitness. 2006; 46, 501-508. 
Isberg L. Anger, aggressive behavior, and Athletic performance. En: Hanin YL, editores. Emotions in sport. Champaign, IL: Human Kinetics; 2000: 113-33.

Oliva F, Calleja N, Hernández R. Escala de creencias sobre la ira en el deporte de combate con atletas mexicanos. Rev Int Med Cienc Act Fís Deporte. 2012; 12: 110-21

Robazza C, Bortoli L. Perceived impact of anger and anxiety on sporting performance in rugby players. Psychol Sport Exerc. 2007; 8: 875-896.

Pagonis TA, Angelopoulus NV, Koukoulis GN, Hadjichristodoulou CS, Toli PN. Psychiatric and hostility factors related to use of anabolic steroids in monozygotic twins. Eur Psychiatry. 2006; 21: 563-9.

Pope HG, Kouri EM, Hudson JI. Effects of supraphysiologic doses of testosterone on mood and aggression in normal men: a randomized controlled trial. Arch Gen Psychiatry. 2000; 57: 133-40.

Salvador A, Suay F, González-Bono E, Serrano MA. Anticipatory cortisol, testosterone and psycological responses to judo competition in young men. Psychoneuroendocrinology. 2003; 28: 364-375.

Suay F, Salvador A, González E, Sanchis C, Simón V, Montoro J. Testosterona y evaluación de la conducta agresiva en jóvenes judokas. Rev Psicol Dep. 1996; 9: 77-93.

Serrano MA, Salvador A, González-Bono E, Sanchís C, Suay F. Hormonal responses to competition. Psicothema. 2000; 12: 440-444.

Evans NA. Current concepts in anabolic-androgenic steroids. Am J Sports Med. 2004; 32: 534-42

Sekulic D, Zenic N, Versic S, Maric D, Gabrilo G, Jelicic M. The Prevalence and Covariates of Potential Doping Behavior in Kickboxing; Analysis among High-Level Athletes. J Hum Kinet. 2017 59: 67-77.

Brenu EW, McNaughton L, Marshall-Gradisnik SM. Is there a potential immune dysfunction with anabolic androgenic steroid use?: A review. Mini Rev Med Chem. 2011; 11: 438-45.

Saudan C, Baume N, Robinson N, Avois L, Mangin P, Saugy M. Testosterone and doping control. Br J Sports Med. 2006; 40 Suppl 1: i21-4.

Young RJ, Ismail AH, Bradley A, Corrigan DL. Effect of prolonged exercise of serum testosterone levels in adult men. Br J Sports Med. 1976; 10: 230-5.

Hiruntrakul A, Nanagara R, Emasithi A, Borer KT. Effect of endurance exercise on resting testosterone levels in sedentary subjects. Cent Eur J Public Health. 2010; 18: 169-72.

Hayes LD, Sculthorpe N, Herbert P, Baker JS, Hullin DA, Kilduff LP, et al. Resting steroid hormone concentrations in lifetime exercisers and lifetime sedentary males. Aging Male. 2015; 18: 22-6.

Chiprut R, Castellanos-Urdaibay A, Sánchez-Hernández C, MartínezGarcía D. La obesidad en el siglo XXI. Avances en la etiopatogenia y tratamiento. Gaceta Med Mex. 2001; 137: 323-34.

Lewis J. Steroid Analysis in Saliva: An overview. Clin Biochem Rev. 2006; 27 : 139-46.

Gröschl M. Current status of salivary hormone analysis. Clin Chem. 2008; 54: 1759-69.

Hayes LD, Sculthorpe N, Cunniffe B, Grace F. Salivary Testosterone and Cortisol Measurement in Sports Medicine: a Narrative Review and User's Guide for Researchers and Practitioners. Int J Sports Med. 2016; 37(13): 1007-18.

Bassas-Arnau L. Exploración de la función testicular. Endocrinol Nutr. 2009; 56(1): 18-31.

Keskin MZ, Budak S, Aksoy EE, Yücel C, Karamazak S, Ilbey YO, et al. Investigation of the effect of body mass index (BMI) on semen parameters and male reproductive system hormones. Arch Ital Urol Androl. 2017; 89: 219-221.

Figueroa-Valverde L, García-Cervera E, Díaz-Cedillo F, Camacho-Luis A. Correlación entre testosterona, presión sanguínea, índice de masa corporal y edad en varones jóvenes. Rev Int Androl 2009; 7: 142-9.

Shamim MO, Ali Khan FM, Arshad R. Association between serum total testosterone and Body Mass Index in middle aged healthy men. Pak J Med Sci. 2015; 31: 355-9.

Fui MN, Dupuis P, Grossmann M. Lowered testosterone in male obesity: mechanisms, morbidity and management. Asian J Androl. 2014; 16: 223-31.

Singh P. Andropause: Current concepts. Indian J Endocrinol Metab. 2013; 7: 621-9.

Kelsey TW, Li LQ, Mitchell RT, Whelan A, Anderson RA, Wallace WH. A Validated Age-Related Normative Model for Male Total
Testosterone Shows Increasing Variance but No Decline after Age 40 Years. PLoS One. 2014; 9: e109346.

Araujo AB, Wittert GA. Endocrinology of the Aging Male. Best Pract Res Clin Endocrinol Metab. 2011; 25: 303-319.

Hayes LD, Herbert P, Sculthorpe NF, Grace FM. Exercise training improves free testosterone in lifelong sedentary aging men. Endocr Connect. 2017; 6: 306-10.

Devi S, Saxena J, Rastogi D, Goel A, Saha S. Effect of short-term physical exercise on serum total testosterone levels in young adults. Indian J Physiol Pharmacol. 2014; 58: 178-81.

Vogel RB, Books CA, Ketchum C, Zauner CW, Murray FT. Increase of free and total testosterone during submaximal exercise in normal males. Med Sci Sports Exerc. 1985; 17: 119-23.

Gorostiaga EM, Izquierdo M, Ruesta M, Iribarren J, González-Badillo JJ, Ibáñez J. Strength training effects on physical performance and serum hormones in young soccer players. Eur J Appl Physiol. 2004; 91: 698707.

Ahtiainen JP, Pakarinen A, Alen M, Kraemer WJ, Häkkinen K. Muscle hypertrophy, hormonal adaptations and strength development during strength training in strength-trained and untrained men. Eur J Appl Physiol. 2003; 89: 555-63.

De Souza MJ, Arce JC, Pescatello LS, Scherzer HS, Luciano AA. Gonadal hormones and semen quality in male runners. A volume threshold effect of endurance training. Int J Sports Med, 1994; 15: 383-391.

Wheeler GD, Wall SR, Belcastro AN, Cumming DC. Reduced serum testosterone and prolactin levels in male distance runners. JAMA. 1984; 252: 514-6.

Alén M, Pakarinen A, Häkkinen K, Komi PV. Responses of serum androgenic-anabolic and catabolic hormones to prolonged strength training. Int J Sports Med. 1988; 9: 229-33.

Andreato LV, Lara FJD, Andrade A, Branco BHM. Physical and Physiological Profiles of Brazilian Jiu-Jitsu Athletes: a Systematic Review. Sports Med Open. 2017; 3:9.

Ouergui I, Davis P, Houcine N, Marzouki H, Zaouali M, Franchini E, et al. Hormonal, Physiological, and Physical Performance During Simulated Kickboxing Combat: Differences Between Winners and Losers. Int J Sports Physiol Perform. 2016; 11: 425-31.

James LP, Beckman EM, Kelly VG, Haff GG. The Neuromuscular Qualities of Higher- and Lower-Level Mixed-Martial-Arts Competitors. Int J Sports Physiol Perform. 2017; 12: 612-620.

James LP, Haff GG, Kelly VG, Beckman EM. Towards a Determination of the Physiological Characteristics Distinguishing Successful Mixed Martial Arts Athletes: A Systematic Review of Combat Sport Literature. Sports Med. 2016; 46: 1525-51.

Zitzmann M, Nieschlag E. Testosterone levels in healthy men and the relation to behavioural and physical characteristics: facts and constructs. Eur J Endocrin. 2001; 144: 183-97.

Archer J. The influence of testosterone on human aggression. Br. J. Psychol. 1991; 82: 1-28.

Archer J. Testosterone and human aggression: an evaluation of the challenge hypothesis. Neurosci Biobehav Rev. 2006; 30: 319-45.

Josephs RRA, Mehta PPH, Carré JMJ. Gender and social environment modulate the effects of testosterone on social behavior: comment on Eisenegger et al.et al. Trends Cogn. Sci. 2001; 15: 509-10.

Wingfield JC, Hegner RE, Dufty AM, Ball GF. The "Challenge Hypothesis": thoeretical implications for patterns of testosterone secrtion, mating systems, and breeding strategies. Am. Nat. 1990; 136: 829-46.

Fabio RA, Towey GE. Cognitive and personality factors in the regular practice of martial arts. J Sports Med Phys Fitness. 2017 In press.

Woodward TW. A review of the effects of martial arts practice on health. WMJ. 2009; 108(1): 40-3. 
Table 1. Total testosterone values and age.

\begin{tabular}{|l|l|l|l|}
\hline \multicolumn{3}{|l|}{ Martial Artists } & \multicolumn{2}{l|}{ Athletes } \\
\hline Age & Testosterone & Age & Testosterone \\
\hline 35 & 6.17 & 18 & 5.98 \\
24 & 8.38 & 23 & 8.32 \\
26 & 5.25 & 27 & 6.32 \\
25 & 6.91 & 26 & 7.00 \\
19 & 5.62 & 26 & 6.42 \\
23 & 7.34 & 25 & 4.01 \\
25 & 5.94 & 25 & 6.1 \\
25 & 5.71 & 29 & 6.92 \\
26 & 4.07 & 26 & 6.24 \\
21 & 7.62 & 20 & 7.81 \\
22 & 7.49 & 27 & 3.83 \\
35 & 5.42 & 25 & 6.62 \\
34 & 6.39 & 18 & 6.25 \\
35 & 7.97 & 23 & 3.90 \\
28 & 6.28 & 18 & 5.65 \\
\hline $\mathbf{2 6 . 8}(\mathbf{\pm 5 . 3})$ & $\mathbf{6 . 4 4}(\mathbf{\pm 1 . 1 7})$ & $\mathbf{2 3 . 7}(\mathbf{\pm 3 . 6})$ & $\mathbf{6 . 0 9}(\mathbf{+ 1 . 3 2})$ \\
years & $\mathbf{n g} / \mathbf{m L}$ & years & $\mathbf{n g} / \mathbf{m L}$ \\
\hline
\end{tabular}

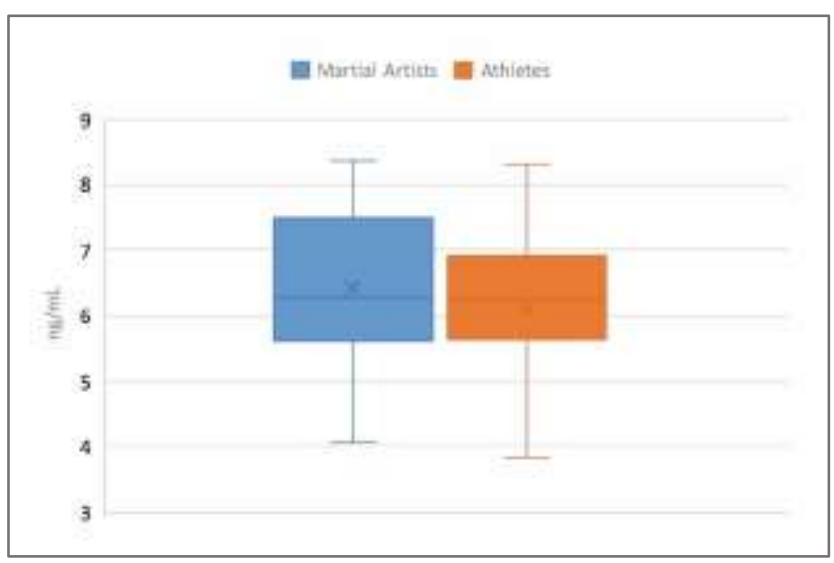

Figure 1. Basal serum testosterone level in martial artists and athletes. 